\title{
PENGARUH COOPERATIVE PLAY PUZZLE TERHADAP KEMAMPUAN BERADAPTASI SOSIAL PADA ANAK TUNAGRAHITA
}

\begin{abstract}
Riskayani $^{{ }^{*}}$, Ika Arum Dewi ${ }^{2}$, Ari Damayanti ${ }^{3}$
${ }^{1}$ Sekolah Tinggi Ilmu Kesehatan Widyagama Husada Malang

${ }^{2}$ Sekolah Tinggi Ilmu Kesehatan Widyagama Husada Malang

${ }^{3}$ Sekolah Tinggi Ilmu Kesehatan Widyagama Husada Malang Jurusan

Corresponding author:

Ika Arum Dewi

Sekolah Tinggi Ilmu Kesehatan Widyagama

Husada Malang

Email: ikaarumds@gmail.com

Abstract

Background: Retardation was a big world problem, especially for developing countries. The ability to socialize in mental retardation children did not develop optimally which caused the child to be not independent, unable to communicate directly in two directions with friends or other people. Objective: To find out the effect of cooperative play puzzles on the social adaptability of mental retardation children. Method: This study used a quasy experimental design with a pretest posttest one group design approach. The sampling technique used purposive sampling with an instrument in the form of observation of the social adaptation ability checklist sheet. The number of respondents was 10 people. The statistical test used Wilcoxon Sign Rank test to determine the effect of the cooperative play puzzle variable on the social adaptation ability of mental retardation children. Result: Most of the respondents had enough capability of social adaptability before being given play therapy, as many as 6 respondents $(60 \%)$, and after being given play therapy intervention suggested that almost all respondents were capable to social adaptability, as many as 9 respondents (90\%). In the Wilcoxon Sign Rank test, the value of $p=0.004$ or $H_{0}$ was rejected, meaning that there was a significant effect of Cooperative Play Puzzle on the social adaptation ability of mental retardation children.Conclusion: Cooperative play puzzles could improve social adaptability in mental retardation children.
\end{abstract}

Keywords: cooperative play puzzle; social adaptability; mental retardation.

\begin{abstract}
Abstrak
Latar Belakang: Tunagrahita merupakan masalah dunia yang besar terutama bagi negara berkembang. Kemampuan sosialisasi pada anak Tunagrahita tidak berkembang secara optimal yang menyebabkan anak tidak mandiri, tidak dapat berkomunikasi langsung dua arah dengan teman atau orang lain. Tujuan: Mengetahui pengaruh cooperative play puzzle terhadap kemampuan beradaptasi sosial pada anak Tunagrahita. Metode: Penelitian ini menggunakan desain quasy experimental dengan pendekatan pretest posttest one group design. Teknik sampling menggunakan purposive sampling dengan instrument berupa observasi lembar checklist kemampuan adaptasi sosial. Jumlah responden adalah 10 orang. Uji statistik yang digunakan adalah uji WIlcoxon Sign Rank untuk mengetahui pengaruh variabel cooperative play puzzle terhadap kemampuan adaptasi sosial anak tunagrahita. Hasil: Sebagian besar responden cukup mampu dalam beradaptasi sosial sebelum diberikan terapi bermain yaitu 6 responden $(60 \%)$, dan sesudah diberikan intervensi terapi bermain menunjukkan bahwa hampir seluruh responden mampu beradaptasi sosial yaitu 9 responden (90\%). Pada uji Wilcoxon Sign Rank didapatkan nilai $\mathrm{p}=0,004$ atau $\mathrm{H}_{0}$ ditolak artinya ada pengaruh yang signifikan Cooperative Play Puzzle terhadap Kemampuan Adaptasi Sosial pada Anak Tunagrahita. Kesimpulan: Cooperative play puzzle dapat meningkatkan kemampuan beradaptasi sosial pada anak tunagrahita.
\end{abstract}

Kata Kunci: cooperative play puzzle; kemampuan adaptasi sosial; tunagrahita. 


\section{PENDAHULUAN}

Retardasi Mental adalah suatu keadaan dimana anak mengalami suatu limitasi atau keterbatasan yang bermakna baik dalam fungsi intelektual maupun perilaku adaptif yang diekspresikan dalam keterampilan konseptual, sosial dan praktis (Hendra.U, 2013).

Retardasi mental merupakan masalah dunia yang besar terutama bagi negara berkembang. Dari hasil World Health Organization (WHO) memperkirakan angka terjadinya retardasi mental berat sekitar 1-3\% dari seluruh populasi, dan hampir $3 \%$ memiliki IQ di bawah 70. Sebagai sumber daya manusia tentunya mereka tidak dapat dimanfaatkan, karena 0,1 \% dari anak-anak yang memiliki IQ rendah ini sangat diperlukan perawatan, bimbingan serta pengawasan seumur hidupnya. Sedangkan di Indonesia jumlah anak berkebutuhan khusus sekitar 7\% dari total jumlah anak usia 0-18 tahun atau sebesar 6.230.000. Terjadi retardasi mental 1,5 kali lebih banyak laki-laki dari pada dibandingkan dengan perempuan, dimana insiden tertinggi pada masa anak sekolah pada usia 6 sampai 17 tahun (Ramayumi, 2014). Berdasarkan data Riset Kesehatan Dasar (Riskesdas, 2018), jumlah penyandang disabilitas di Indonesia sebesar 3,3\% dari total populasi. Angka terjadinya retardasi mental di Jawa Timur sekitar 3,22\% sedangkan di Malang termasuk dalam kategori tertinggi kedua sekitar $10 \%$ proporsi disabilitas anak usia 5-17 tahun.

Gangguan adaptasi sosial pada anak Retardasi Mental dapat disebabkan karena anak tersebut mengalami fungsi intelektual di bawah rata-rata sehingga sulit untuk melakukan kegiatan yang sama seperti anak normal biasanya. Kemampuan sosialisasi pada anak Retardasi Mental tidak berkembang secara optimal yang menyebabkan anak tidak mandiri, tidak dapat berkomunikasi langsung dua arah dengan teman atau orang lain, tidak dapat melaksanakan tugasnya sebagai anggota masyarakat yang sesuai ketentuanketentuan mengenai suatu pola perilaku sosial yang normal.

Perkembangan keterampilan emosional dan sosial pada anak RM ringan dan sedang dapat dioptimalkan dengan menggunakan terapi bermain berupa bentuk permainan cooperative play dengan puzzle. Cooperative play adalah permainan yang melibatkan interaksi sosial dalam kelompok dimana dapat ditemui indentitas kelompok dan kegiatan yang terorganisir antara pemimpin dan anggota kelompok. Dalam cooperative play disini, salah satu yang diterapkan adalah puzzle. Puzzle merupakan salah satu permainan yang dapat meningkatkan kreativitas dan merangsang kecerdasan anak, karena puzzle merupakan sutau masalah atau misteri yang harus dipecahkan. Dalam terapi bermain cooperative play ini, permainan puzzle dilakukan secara berkelompok. Setiap anak saling berkomunikasi dan berinteraksi dalam menyusun puzzle. Peran peneliti dalam terapi bermain ini sebagai fasilitator, mendukung, dan mendorong terjadinya proses interaksi anak saat dilakukan permainan. Permainan puzzle yang dilakukan secara berkelompok dapat meningkatkan kemampuan interpersonal anak. Sehingga kemampuan sosialisasinya dapat meningkat.

Pada dasarnya dengan menggunakan metode bermain puzzle kegiatan pembelajaran anak lebih efektif dan menyenangkan, membangkitkan keinginan dan minat yang baru, dapat menimbulkan motivasi dan rangsangan kegiatan belajar dan bahkan membawa pengaruh-pengaruh psikologi terhadap anak (Situmorang,2012). Selain itu permainan puzzle merupakan permainan yang berhubungan dengan daya kreatifitas dan ingatan siswa lebih mendalam sehingga anak Retardasi Mental dapat melatih kesabaran, meningkatkan keterampilan motorik halusnya, serta dapat menngkatkan kecerdasan. (Mollie \& Rusell S, 2010). 
Berdasarkan hasil penelitian dan beberapa teori yang telah ditemukan dapat disimpulkan bahwa permainan puzzle dapat meningkatkan adaptasi sosial anak dimana dengan permainan puzzle secara kelompok anak akan berlajar berkomunikasi dengan baik dengan temannya dalam memecahkan teka-teki dalam permainan puzzle selain itu juga dengan permainan puzzle ini anak dituntut untuk berfikir lebih aktif sehingga dapat memancing respon dan daya fikir anak, dengan terjalinnya komunikasi yang baik dari anak satu dan lainnya akan meningkatkan hubungan sosial anak yang baik dengan teman satu kelompok. (Wulandari dkk, 2018)

Hasil penelitian terakhir yang diteliti oleh (Wulandari et al., 2018) diharapkan dapat melakukan upaya meningkatkan kesehatan anak dengan retardasi mental dengan melakukan terapi-terapi kelompok pada anak dengan retardasi mental secara berkala dengan tenga-tenaga kesehatan yang terlatih dibidangnya sehingga sosial anak dengan retardasi mental dapat diminimalkan.

Pada SD SLB di Lawang yang mengalami Retardasi Mental sebanyak 68 anak, 54 anak retardasi mental IQ sedang dan 14 anak retardasi mental IQ ringan. Pada SLB di Lawang tersebut belum pernah diberikan terapi bermain yang membantu adaptasi sosial pada anak retardasi mental. Sehingga peneliti ingin melakukan penelitian tentang pengaruh terapi bermain : cooperative play puzzle terhadap kemampuan beradaptasi sosial pada anak retardasi. Bahan puzzle yang akan digunakan peneliti adalah berbahan MDF (Medium Density FiberBoard) dan kayu.

Berdasarkan uraian diatas, peneliti merasa perlu melakukan upaya untuk mengatasi masalah siswa tersebut dengan mencari strategi atau metode yang efektif untuk meningkatkan beradaptasi tersebut. Metode yang akan digunakan untuk mencapai beradaptasi sosial dengan metode cooperative play bermain menggunakan media puzzle. Aktivitas dengan media puzzle dapat mempengaruhi adaptasi sosial pada anak. Media puzzle merupakan media gambar yang termasuk kedalam media visual karena dapat dicerna melalui indera penglihatan. Puzzle adalah permainan yang menyusun suatu gambar menjadi bentuk utuh dari kepingan-kepingan. Pembelajaran dengan penggunaan media puzzle anak dapat melatih intelegensi dalam memecahkan masalah, anak akan dilatih untuk berfikir dan aktif dalam interaksi bersama kelompok.

\section{METODE}

Penelitian ini menggunakan desain quasy experimental dengan pendekatan pretest posttest one group design. Teknik sampling menggunakan purposive sampling dengan instrument berupa observasi lembar checklist kemampuan adaptasi sosial. Jumlah responden adalah 10 orang. Variabel penelitian adalah cooperative play puzzle sebagai variabel independen dan kemampuan adaptasi sosial pada anak tunagrahita sebagai variabel dependen. Alat ukur menggunakan checklist kemampuan adaptasi sosial. Uji statistik yang digunakan adalah uji Wilcoxon Sign Rank.

Penelitian dilakukan dengan waktu 2 minggu yang dibagi menjadi beberapa tahap yaitu ; melakukan pretest kemampuan adaptasi sosial pada anak RM yang dilakuakn secara tatap muka, dilanjutkan dengan pemberian intervensi cooperative play puzzle (3 pertemuan) via daring, masing-masing pertemuan berdurasi 30 menit. Kegiatan berikutnya yakni post test kemampuan adaptasi sosial via daring. Dari data yang diperoleh, peneliti melakukan analisa tentang adanya pengaruh cooperative play terhadap kemampuan adaptasi sosial.

\section{HASIL DAN PEMBAHASAN}

Tabel 1. Karakteristik Responden 


\begin{tabular}{|c|c|c|}
\hline Variabel & $\begin{array}{c}\text { Jumlah } \\
\text { (n) }\end{array}$ & $\begin{array}{c}\text { Prosentase } \\
(\%)\end{array}$ \\
\hline \multicolumn{3}{|l|}{ Usia } \\
\hline 10 tahun & 2 & 20,0 \\
\hline 11 tahun & 4 & 40,0 \\
\hline 12 tahun & 4 & 40,0 \\
\hline \multicolumn{3}{|l|}{ Jenis Kelamin } \\
\hline Laki-laki & 6 & 60,0 \\
\hline Perempuan & 4 & 40,0 \\
\hline \multicolumn{3}{|l|}{ Lama Pendidikan } \\
\hline 5 tahun & 6 & 60,0 \\
\hline 6 tahun & 4 & 40,0 \\
\hline \multicolumn{3}{|l|}{ Kebiasaan di rumah } \\
\hline Menonton TV & 4 & 40,0 \\
\hline Bermain sendiri & 2 & 20,0 \\
\hline Bermain dengan teman & 4 & 40,0 \\
\hline \multicolumn{3}{|l|}{ Pendidikan Ayah } \\
\hline Lulus SLTP/sederajat & 8 & 80.0 \\
\hline Lulus SLTA/sederajat & 2 & 20.0 \\
\hline Pendidikan Ibu & 10 & 27 \\
\hline Lulus SD/sederajat & 1 & 10.0 \\
\hline Lulus SLTP/sederajat & 8 & 80.0 \\
\hline Lulus SLTA/sederajat & 1 & 10.0 \\
\hline \multicolumn{3}{|l|}{ Pekerjaan Ayah } \\
\hline Swasta & 3 & 30,0 \\
\hline Petani & 1 & 10,0 \\
\hline Lain-lain & 6 & 60,0 \\
\hline \multicolumn{3}{|l|}{ Kedudukan Anak } \\
\hline Anak Pertama & 7 & 70,0 \\
\hline Anak Kedua & 3 & 30,0 \\
\hline \multicolumn{3}{|l|}{ Jumlah Anak } \\
\hline Satu Anak & 3 & 30,0 \\
\hline Dua Anak & 7 & 70,0 \\
\hline \multicolumn{3}{|c|}{ Riwayat Keluarga Tunagrahita } \\
\hline Tidak ada riwayat $\mathrm{RM}$ & 10 & 100,0 \\
\hline \multicolumn{3}{|l|}{ Riwayat Penyakit } \\
\hline Tidak Ada & 3 & 30,0 \\
\hline Ada & 7 & 70,0 \\
\hline \multicolumn{3}{|l|}{ Riwayat Persalinan } \\
\hline Normal & 3 & 30,0 \\
\hline Dengan penyulit & 7 & 70,0 \\
\hline
\end{tabular}

SLB Lawang Kabupaten Malang merupakan SLB yang menampung siswa untuk jenjang pendidikan SD dan SMP. Hasil penelitian diketahui bahwa hampir setengah responden berumur 11 dan 12 tahun yaitu masing-masing 4 responden (40\%). Tahap Masa Praremaja (6-12 tahun) mempunyai ciri-ciri teman sebaya sangat penting, anak mulai berpikir logis, meskipun masih kongkrit dan operasional, egosentris berkurang, memori dan kemampuan bahasa meningkat, kemampuan kognitif meningkat akibat sekolah formal, dan konsep diri berubah, yang mempengaruhi harga dirinya (Setjiningsih \& Ranuh, 2014).

Usia responden sudah mendekati usia remaja, seharusnya mereka sudah sangat mementingkan teman sebaya, sehingga pada masa ini harus memiliki kemampuan beradaptasi sosial yang baik, karena mereka sangat membutuhkan teman sebaya untuk mendukung perkembangannya, namun pada anak Tunagrahita, perkembangan tersebut tidak selalu dapat berjalan dengan baik, sehingga usia yang mendekati remaja pun belum tentu mempunyai kemampuan adaptasi sosial yang baik, masih banyak faktor lain yang mempengaruhi kemampuan adaptasi sosial anak. Pada Anak Tunagrahita di SLB Pembina Tingkat Nasional Bagian C Malang dengan usia yang sudah memasuki usia remaja tidak menutup kemungkinan untuk melakukan adaptasi sosial dengan anak yang dibawah usia. Sehingga, anak tunagrahita dapat melakukan proses adaptasi cukup baik dalam proses terapi yang dilakukan. Usia tidak berpengaruh dalam proses adaptasi sosial, dengan adanya penelitian ini dilakukan pada saat pandemi sangatlah tepat ketika responden beradaptasi dengan keluarga dirumah dan sebaliknya keluarga lebih mengetahui perkembangan maupun perbedaan anak pada saat belajar dirumah maupun disekolah.

Hasil penelitian diketahui bahwa sebagian besar responden adalah laki-laki yaitu 6 responden $(60 \%)$. Retardasi mental 1,5 kali lebih banyak laki-laki dari pada dibandingkan dengan perempuan, dimana insiden tertinggi pada masa anak sekolah pada usia 6 sampai 17 tahun (Ramayumi, 2014). Sesuai dengan teori tersebut karena jumlah responden disini adalah 1,5 kali lipat dibandingkan banyaknya responden perempuan, namun secara teoritis belum diketahui secara pasti mengapa anak laki-laki lebih berisiko mengalami retardasi mental dibandingkan anak perempuan. Jenis kelamin bukan acuan faktor terjadinya tunagrahita dikarenakan penyakit ini bisa terjadi pada laki-laki maupun perempuan. Menurut Percy and Schormans (2003) sebagai cacat intelektual yang paling umum yang disebabkan faktor genetik yang berlebihan kromosom 21 pada sel tubuh. 
Hasil penelitian diketahui bahwa sebagian besar responden adalah telah menempuh pendidikan selama 5 tahun yaitu 6 responden (60\%). Pada anak dengan retardasi mental memiliki kemampuan mudah latih (trainable) dan sulit didik (uneducable). Dengan demikian, proses pembelajarannya lebih berfokus pada kegiatan melatih pada anak dengan keterampilan yang memungkinkan mereka untuk dapat berfungsi pada lingkungan sosial. Program pelatihan khusus yang diberikan pada anak retardasi mental dilaksanakan sesuai dengan batas kemampuan anak (Lisnawati, 2014). Kemampuan adaptasi sosial juga berhubungan dengan lama anak dalam menempuh pendidikan, anak retardasi mental yang mudah latih, dengan pendidikan selama 5 tahun seharusnya sudah dapat mengikuti pembejalaran dan beradaptasi dengan lingkungan sosialnya terutama apabila sedang berada di sekolah, akan tetapi hal ini sifatnya juga individual tergantung dari penerimaan setiap anak terhadap pembelajaran yang diberikan di sekolah. Dalam proses penelitian dilakukan poin dalam pendidikan sangat berpengaruh dalam adaptasi sosial karna ada responden yang mengalami penambahan dalam pendidikan.

Hasil penelitian diketahui bahwa hampir setengah responden mempunyai kebiasaan menonton TV dan bermain dengan teman yaitu 4 responden (40\%). Melalui kegiatan bermain, anak akan belajar memberi dan menerima. Bermain dengan orang lain akan membantu anak untuk mengembangkan hubungan sosial dan belajar memecahkan masalah dari hubungan sosial dan belajar memecahkan masalah dari hubungan tersebut (Musfiroh, 2012). Anak yang mempunyai kebiasaan menonton TV di rumah dan tidak bergaul dengan temannya akan cenderung mempunyai kemampuan adaptasi sosial yang lebih rendah dibandingkan dengan anak yang bermain dengan temannya, karena saat bermain bersama temannya, anak belajar untuk bersosialisasi, berkomunikasi, dan bekerja sama meskipun tidak menutup kemungkinan saat mereka bermain bersama temannya, mereka sibuk dengan permainannya sendiri, karena perilaku anak retardasi mental tidak seperti anak normal pada umumnya. Kegiatan dirumah pada 6 reponden lainnya dilakukan dirumah tidak diluar memiliki alasan yang membuat keluarga khawatir dengan keselamtan maupun kenyamanan anak. Salah satunya menghindari terjadinya bullying pada anak.

Hasil penelitian diketahui bahwa hampir seluruh responden mempunyai ayah dengan pendidikan SLTP/sederajat yaitu 8 responden (80\%), sedangkan diketahui bahwa bahwa hampir seluruh responden mempunyai ibu dengan pendidikan SLTP/sederajat yaitu 8 responden (80\%). Pendidikan orang tua yang baik maka orang tua dapat menerima segala informasi dari luar terutama tentang pengasuhan anak yang baik dan cara-cara melatih anak untuk bersosialisasi dengan lingkungan sekitarnya (Basrowi, 2014). Pendidikan orang tua sangat penting dalam perkembangan anak, karena orang tua adalah orang yang terdekat dengan anak, yang dicontoh dan ditiru oleh anak sehingga orang tua yang mempunyai pendidikan rendah akan cenderung mempunyai wawasan yang lebih sedikit dibandingkan dengan orang tua yang berpendidikan tinggi karena kemampuan menyerap dan menyimpan informasi yang kurang. Kurangnya wawasan dan pengetahuan orang tua tentang cara mendidik anak retardasi mental, cara melakukan stimulsi kemampuan adaptasi sosial, akan mempengaruhi perkembangan anak secara langsung, sehingga anak yang memiliki orang tua dengan pendidikan rendah akan cenderung mempunyai kemampuan adaptasi sosial yang kurang, meskipun tidak semuanya demikian, karena informasi juga bisa didapatkan di luar pendidikan formal apabila orang tua aktif mencari informasi tentang stimulasi 
kemampuan adaptasi sosial anak, maka anak bisa memiliki kemampuan yang baik.

Hasil penelitian diketahui bahwa sebagian besar responden mempunyai ayah dengan pekerjaan lainlain seperti wirausaha, tukang ojek, pedagang yaitu 6 responden (60\%). Anak yang memiliki tingkat sosioekonomi yang tinggi akan menyukai kegiatan permainan yang memiliki nilai ekonomis yang tinggi, seperti sepatu roda atau lomba atletik dengan temannya. Sebaliknya, anak yang memiliki tingkat sosio ekonomi yang rendah akan bermain dengan alatalat yang memiliki nilai ekonomis yang tidak mahal seperti, bola, kelereng atau berenang (Delphie, 2012). Pekerjaan orang tua merupakan paramater kondisi sosial ekonomi keluarga, orang tua dengan pekerjaan yang kurang tinggi dari segi ekonomi, artinya tidak memberikan penghasilan yang besar membuat keluarga kurang mampu untuk membelikan alat permainan edukatif yang mampu menstimulasi perkembangan anak, salah satunya adalah kemampuan adaptasi sosial sehingga membuat anak tidak benar-benar mampu menjalankan adaptasi sosial bersama anak-anak lain seperti tidak mampu membelikan mainan yang sama dengan anak lain sehingga responden tidak dapat bergabung bermain bersama dengan teman sebayanya.

Hasil penelitian 1 diketahui bahwa sebagian besar responden memiliki penyakit yaitu 7 responden (70\%), dan tabel 5.12 diketahui bahwa sebagian besar responden dilahirkan dengan riwayat ada penyulit persalinan yaitu 7 responden (70\%). Faktor pascanatal yang dapat menimbulkan kerusakan otak yang dapat mengakibatkan terjadinya tunagrahita pada anak diantaranya adalah infeksi (meningitis, ensefalitis, dan infeksi di bagian tubuh lain yang menahun), trauma kapitis, tumor otak, kelainan tulang tengkorak, dan keracunan pada otak. Kesehatan pada ibu yang buruk dan terlalu sering melahirkan merupakan penyebab komplikasi kelahiran seperti bayi lahir prematur, perdarahan postpartum dan sebagainya (Marmis, 2009). Dari hasil wawancara maupun data yang didapat dari penelitian $70 \%$ responden memiliki penyebab terjadinya tunagrahita sesuai sumber dari Hallahan \& Kauffan (2006) yang menyebutkan penyebab dari luar adalah demam yang terlalu tinggi, gangguan pada otak, keracunan waktu ibu hamil.

Tabel 2. Kemampuan Adaptasi Sosial Sebelum dan Sesudah Cooperatif Play Puzzle pada Anak Tunagrahita

\begin{tabular}{lcccc}
\hline \multicolumn{1}{c}{ Kriteria } & \multicolumn{2}{c}{ Sebelum } & \multicolumn{2}{c}{ Sesudah } \\
\cline { 2 - 5 } & F & \% & F & $\%$ \\
\hline Kurang Mampu & 4 & 40,0 & 0 & 0 \\
Cukup Mampu & 6 & 60,0 & 1 & 10,0 \\
Mampu & 0 & 0 & 9 & 90,0 \\
\hline Total & 10 & 100,0 & 10 & 100,0 \\
\hline Uji Wilcoxon & pvalue $=0,004$ & \multicolumn{2}{c}{$\alpha=0,05$} \\
\hline
\end{tabular}

Hasil penelitian pada tabel 5.13 diketahui bahwa sebagian besar responden cukup mampu dalam beradaptasi sosial yaitu 6 responden $(60 \%)$, dan 4 responden (40\%) kurang mampu beradaptasi sosial.

Anak tunagrahita mengalami kesukaran dalam berinteraksi dengan orang lain karena keterbatasan intelektual. Keterbatasan intelektual dapat mengakibatkan anak mengalami kesulitan mempelajari norma-norma yang berlaku di masyarakat dan berimbas pada kegagalan dalam penyesuaian sosial. Ketidakmapuan anak tunagrahita melakukan interaksi sosial tidak hanya disebabkan oleh keterbatasan intelektual, tetapi faktor lingkungan juga mempengaruhi cara anak tunagrahita dalam melakukan interaksi sosial. Lingkungan tersebut tidak hanya lingkungan kelas dan sekolah, tetapi juga dari diri anak sendiri, keluarga, dan lingkungan masyarakat sekitarnya (Hurlock, 2012).

Banyak faktor yang mempengaruhi kemampuan adaptasi sosial anak tunagrahita, akan tetapi intelektual adalah faktor utama yang paling penting dalam perkembangan anak retardasi mental, mereka kesulitan dalam berinteraksi sosial dengan orang lain terutama teman sebayanya karena mereka kurang memiliki kemampuan untuk memahami aturan dan norma yang berlaku di masyarakat. Namun, anak 
tunagrahita yang menjadi responden adalah anak yang sudah menempuh pendidikan di SLB selama setidaknya 5 tahun, sehingga sedikit banyak mereka sudah memahami banyak aturan dan norma di masyarakat yang membatasi mereka dalam bertingkah laku dan berinteraksi dengan orang lain, sehingga dalam perkembangannya bukan benar-benar tidak mampu, akan tetapi kurang mampu atau cukup mampu.

Responden yang cukup mampu dalam beradaptasi sosial disebabkan karena anak sudah lama bersekolah, menempuh pendidikan, diajarkan bagaimana hidup bersosial dengan orang lain dan lingkungan, hanya saja mereka tidak mampu menerapkannya secara optimal, sehingga ada beberapa tugas yang mereka belum benar-benar mampu untuk melakukan. Responden yang kurang mampu dapat disebabkan karena faktor intelektual yang lebih rendah dibandingkan dengan yang lain sehingga lebih sulit untuk berinteraksi dengan orang lain.

Hasil penelitian diketahui bahwa hampir seluruh responden mampu beradaptasi sosial yaitu 9 responden (90\%) dan 1 responden (10\%) cukup mampu beradaptasi sosial pada saat proses dilakukam terapi.

Keterampilan sosial berkaitan dalam hal kemampuan berinteraksi dengan orang lain. Puzzle dapat dimainkan secara perorangan. Namun, puzzle dapat dimainkan dengan cara berkelompok. Permainan yang dilakukan oleh anak- anak secara kelompok akan meningkatkan interaksi sosial anak. Dalam kelompok anak akan saling menghargai, saling membantu dan berdiskusi satu sama lain (Rahmawati \& Kurniati, 2010).

Bermain puzzle tidak diterapkan dalam kehidupan anak sehari-hari sehingga anak tidak terbiasa bermain puzzle bersama dengan teman sebaya. Ketika mereka diperkenalkan dengan permainan cooperative puzzle, mereka belajar bagaimana bekerja sama dengan teman untuk menyelesaikan tantangan puzzle, tidak seperti permainan puzzle individu yang selama ini mereka kenal hanya dimainkan sendiri, dengam cooperative play puzzle ini, anak belajar berkomunikasi, bergabung dengan teman yang lain, saling memberitahu, berbagi, bekerja sama membuat responden lebih aktif dalam beradaptasi sosial sehingga hampir seluruh responden meningkat kemampuan adaptasi sosialnya.

Proses terapi dalam penelitian berlangsung dengan situasi pandemi, responden bermain puzzle dengan keluarga sehingga keluarga juga mengetahui proses adaptasi sosial yang anak mereka alami pada saat proses pembelajaran maupun bermain yang saat ini benar-benar dibatasi. Dengan melihat perkembangan yang dialami pada anak. Selain itu, mengetahui cara menerima anak pada saat belajar maupun penyelesaian tugas yang diberikan guru pengajar maupun peneliti.

Hasil penelitian diketahui bahwa seluruh responden mengalami peningkatan kemampuan adaptasi sosial yaitu 10 responden (100\%). Hasil uji Wilcoxon menunjukkan bahwa p value $=0,004$ dan < $\alpha(0,05)$ sehingga $\mathrm{H}_{1}$ diterima dan $\mathrm{H}_{0}$ ditolak sehingga ada pengaruh yang signifikan Cooperative Play Puzzle terhadap Kemampuan Adaptasi Sosial pada Anak Retardasi Mental di SLB Lawang Kabupaten Malang.

Cooperative play puzzle meningkatkan kerjasama kelompok sangat bagus untuk melatih anak berkerja sama dalam memecahkan masalah, dengan melatih kekompakan, membangun kepemimpinan, berempati terhadap orang lain, belajar bertanggung jawab dalam setiap tindakan dan orang lain. Puzzle meningkatkan keterampilan sosial dalam memecahkan suatu masalah dengan temannya selama permainan berlangsung. Keterampilan anak dapat dibentuk melalui saling berbagi, saling bercerita, 
saling berkomunikasi, saling mengungkapkan perasaan dalam bermain, dan adanya dorongan untuk melakukan diskusi dengan teman sebaya di dalam permainan (Delphie, 2012).

Cooperative play puzzle membuat semua responden mengalami peningkatan kemampuan adaptasi sosial, tidak ada satupun responden yang tidak mengalami peningkatan kemampuan adaptasi sosial, hampir seluruh responden telah mampu melakukan adaptasi sosial dengan baik. Responden memainkan puzzle dengan gembira, karena puzzle yang bentuk dan warnanya menarik, gambar yang unik dan menyenangkan sehingga membuat responden tertarik, serta dimainkan bersama dengan yang lain, dibuat sistem kompetisi untuk mendapatkan hadiah, jika tantangan yang diberikan dapat diselesaikan akan mendapatkan hadiah. Sehingga anak-anak semangat untuk bermain dan menjadi lebih akrab dengan teman ataupun keluarga, dengan demikian mereka akan berusaha untuk bekerja sama dengan berkomunikasi yang baik dengan teman lain. Masih ada 1 responden yang hanya meningkat menjadi cukup mampu, karena responden susah sekali untuk bergabung dengan temannya, masih sulit untuk bekerja sama dengan teman yang lain, hal ini dapat disebabkan karena anak sama sekali tidak pernah bergaul dengan orang lain selama di rumah, hal ini membuat anak kesulitan untuk berinteraksi dengan teman yang lain, dapat juga disebabkan karena anak malu, minder, karena merasa dirinya tidak seperti anak normal yang lain.

Dalam penelitian ini puzzle yang digunakan sangat jauh berbeda dari puzzle yang sering digunakan sekolah. Sehingga, responden memiliki suatu hal yang baru dan menarik untuk dilakukan dalam situasi pandemi. Feedback yang didapat sangat memuaskan dari responden maupun wali murid, dengan ,mengungkapkan ucapan terimakasih dan memberikan ilmu maupun permainan baru sehingga responden lebih semngat untuk belajar. Puzzle yang digunakan adalah puzzle hewani yang terdapat angka maupun huruf untuk menarik keinginan anak untuk menyelesaikan puing-puing yang disusun. Secara tidak langsung, anak-anak akan belajar berkomunikasi, adaptasi maupun proses belajar dalam puzzle yang diberikan.

\section{KESIMPULAN}

Kemampuan beradaptasi sosial sebelum mendapatkan terapi bermain : cooperative play puzzle anak tunagrahita sebagian besar cukup mampu. Kemampuan beradaptasi sosial sesudah mendapatkan mendapatkan terapi bermain : cooperative play puzzle anak tunagrahita hampir seluruhnya mampu. Dari Hasil penelitian ini, dapat disimpulkan bahwa ada pengaruh terapi bermain : cooperative play puzzle terhadap kemampuan beradaptasi sosial pada anak tunagrahita di SLB Pembina Tingkat Nasional Bagian C Malang dengan hasil uji Wilcoxon $p$ value $=0,004$

\section{UCAPAN TERIMA KASIH}

Para dosen pembingbing dan seluruh civitas akademis di STIKES Widyagama Husada malang yang telah membantu proses penelitian ini. Selin itu Pihak SLB Pembina Tingkat Nasional Bagian C Malang, yang telah mengizinkan penelitian ini berlangsung.

\section{DAFTAR RUJUKAN}

Aminuddin. (2000). Sosiologi Suatu Pengenal Awal. Jakarta: Raja Grafindo Persada.

Anwar, Saifuddin. (2014). Metode Penelitian. Yogyakarta : Pustaka Pelajar.

Anwar.S. (2014).Sikap Manusia Teori dan Pengukurannya. Jakarta: Pustaka Pelajar. 
Azwar, S. (2010). Penyusunan Skala Psikologi. Yogyakarta : Pustaka Pelajar.

Basrowi. (2014). Pengantar Sosiologi. Bogor: Ghalia Indonesia.

Burhannudin Ichsan. (2016). Pengantar Metodologi Penelitian Kedokteran Dan Kesehatan Masyarakat (S. dr. Triswi Widyanti Mugi Raharjanti, M.Kes, ed.). Surakarta: Muhammadiyah University Press.

Delphie, B. (2012). Pembelajaran Anak Berkebutuhan Khusus. Bandung: Refika

Dominelli, Lena. (2004). Social Work Interventions with Older People in "Social Work: Theory and Practice for a Changing Profession". Cambridge Polite Press.

Durand, V. M. and Barlow, D. H. (2007). Intisari Psikologi Abnormal. Yogyakarta : Pustaka Pelajar.

Hendra,U. (2013). Buku Ajar Psikiatri Edisi ke- 2 : Universitas Indonesia.Jakarta.

Hurlock, Elizabeth B. (2011). Psikologi Perkembangan : Suatu Pendekatan Sepanjang Rentang Kehidupan. Jakarta : Erlangga.

Hurlock. (2012). Perkembangan Anak. Edisi 4. Erlangga: Jakarta.

Ichsan, B., (2016). Pengantar Metodologi Penelitian Kedokteran dan Kesehatan Masyarakat. Surakarta : Muhammadiyah University Press. Imas dan Anggita, Nauri. (2018). Metode Penelitian Kesehatan, Jakarta: Kementerian Kesehatan Republik Indonesia.

Kemis dan Ati Rosnawati. (2013). Pendidikan Anak Berkebutuhan Khusus Tunagrahita. Bandung: PT. Luxima Metro Media.
Liando, Joppy \& Aldjon Dapa. (2007). Pendidikan Anak Berkebutuhan Khusus Dalam Perspektif Sistem Sosial. Jakarta: Departemen Pendidikan Nasional Direktorat Jenderal Pendidikan Tinggi Direktorat Ketenagaan.

Lisnawati. (2014). Analisis Keberhasilan Terapi Bermain terhadap PerkembanganI.

Maramis, W.F. (2009). Retardasi Mental dalam Catatan Ilmu Kedokteran Jiwa Edisi kedua. Surabaya : pusat penerbitan dan percetakan UNAIR.

Maryanto dan Fatimah. (2004). Metodologi Penelitian. Yayasan Cerdas Press. Mataram.

Masturoh Imas, \& Nauri Anggita. (2018). Metodologi Penelitian Kesehatan (Pertama). Kementrian Kesehatan Republik Indonesia.

Musfiroh. (2012). Cerdas Melalui Bermain. PT Grasindo: Jakarta.

Notoatmodjo,S. (2012). Metodologi Penelitian Kesehatan. Jakarta: Rineka Cipta.

Rachmawati dan Kurniati. (2010). Strategi Pengembangan Kreativitas Pada Anak Usia Dini. Kencana Prenada Media Group, Jakarta. Ramayumi. (2014). Karakteristik Penderita Retardasi Mental di SLB Kota Bukit tinggi.

Riset Kesehatan Dasar (Riskesdas). (2018). Badan Penelitian dan Pengembangan Kesehatan Kementerian RI tahun 2018.

Rosnawati, Ati. (2013). Pendidikan Anak Berkebutuhan Khusus Tunagrahita. Bandung: PT. Luxima Metro Media.

Santrock, J. . (2010) Perkembangan Anak. 2nd edn. Jakarta: Erlangga. 
Situmorang, C. (2012). Bermain puzzle kegiatan belajar pengaruh psikologi terhadap anak. Junal Kedokteran Indonesia.

Soekanto, \& Soerjono, (2000). Sosiologi Suatu Pengantar. Jakarta: PT Raja Grafindo Persada.

Soekidjo Notoatmodjo. (2012). Metodologi Penelitian Kesehatan. Jakarta: Rineka Cipta.

Soemantri, Sutjihati. (2012). Psikologi Anak Luar Biasa. Bandung: PT. Refika

Soetjiningsih \& Ranuh, I. G., (2014). Tumbuh Kembang Anak. 2nd penyunt. Jakarta: EGC.

Soetjiningsih. (2012). Perkembangan Anak dan Permasalahannya dalam Buku Ajar I Ilmu Perkembangan Anak Dan Remaja. Jakarta :Sagungseto.

Somantri, S. T. (2007). Psikologi Anak Luar Biasa. Bandung: Penerbit PT. Refika Aditama.

Suparlan. (2004). Manusia, Kebudayaan dan Lingkungan. Jakarta: CV Rajawali.
Supartini. (2012). Buku Ajar Keperawatan Anak. Jakarta: EGC.

Suryana. (2010). Metodologi Penelitian. Bandung : UPI.

Wardani, Naniek Sulistya. 2012. Pengaruh Pendidikan Karakter Pada Pembelajaran Tematik. Universitas Kristen Satyawacana.

Wong, D. L. (2009). Buku Ajar Keperawatan Pediatrik. Jakarta: EGC.

World Health Organization. (2010). World Health Statistic 2010. Ganeva: World Health Organization.

Wulandari, D., Nelvia, \& Saputra, D. (2018). Pengaruh Permainan Puzzle Terhadap Kemampuan Beradaptasi Sosial Siswa Retardasi Mental. 1, 93-107.

Cite this article as: Riskayani. dkk. (2020). Pengaruh Cooperative Play Puzzle Terhadap Kemampuan Beradaptasi Sosial Pada Anak Tunagrahita. Media Husada Journal of Nursing Science. Vol. 1 (No.1), 59-68.

https://doi.org/10.33475/mhjns.vdiisi tim redaksi. 